\title{
American English and British English: Vocabulary and Grammar Differences
}

\author{
Paga Tri Barata, \\ Chongraksat Wittaya School - Pattani - Southern Thailand \\ fagazbarata@gmail.com
}

\begin{abstract}
ARTICLE INFO
Article History:

Accepted: July, $27^{\text {th }} 2020$

Approved: December, $17^{\text {th }} 2020$

Published: December, 2020

Key Words:

American English, British

English, Grammar,

Vocabulary

DOI: $10.35719 / j l i c . v 2 i 2.26$

ABSTRACT

American English and British English are the famous English varieties in the world, although there are lots of varieties in English, but $\mathrm{AmE}$ and $\mathrm{BrE}$ are the most famous, they have lots of differences each other and sometimes those differences make the new learner confused. This research examines about Grammar and Vocabulary differences between American and British English. The researcher uses Qualitative Approach in this research because the researcher explains the results of research in words form, while Library Research is type of research that researcher used, because the sources of this research are several books, articles and others. The findings of this research indicated that are many differences between American English and British English including in the aspects and grammar and vocabulary. The differences are not a big deal for native speakers, but they may confuse non-native speakers of English.
\end{abstract}

\section{INTRODUCTION}

As speakers of language, we all have certain deep-seated notions concerning the nature of language. Like all such fundamental beliefs, these are often wrong, though they may contain a germ of truth. For example, as literate beings, we tend to equate language with writing. But there are significant differences, not only between oral sounds and written symbols, but also between spoken and written syntax or vocabulary (Laurel and Donna, 2010). 


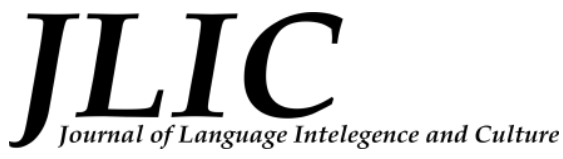

In numbers of speakers as well as in its uses for international communication and in other less quantifiable measures, English is on the most important languages of the world. Spoken by more than 380 million people in the United Kingdom, the United States, and the former British Empire, it is the largest of the Western languages. English, however, is not the most widely used native language in the world. Chinese, in its eight spoken varieties, is known to 1.3 billion people in China alone. Some of the European languages are comparable to English in reflecting the forces of history, especially regarding European expansion since the sixteenth century. Spanish, next in size to English, is spoken by about 330 million people, Portuguese by 180 million, Russian by 175 million, Germany by 110 million, French by 80 million native speakers (and a large number of second-language speakers), Italian by 65 million (Albert C. Baugh \& Thomas Cable, 2002)

Although English is important for international language, most non-native speakers of English find it difficult in learning English, and on the other hand some of them may confuse because English has many varieties such as American English (AmE), British English (BrE), Australian English. the big differences are about English America and English Britain in which they have some differences about vocabulary, grammar also pronunciation. A beginner will shock if they think so much about these differences.

The question is, why English has many varieties? Here is the answer, (David Crystal, 2003) explained that the historical account traces the movement of English around the world, beginning with the pioneering voyages to the Americas, Asia, and the Antipodes. It was an expansion which continued with the nineteenth-century colonial developments in Africa and South Pacific, and which took a significant further step when it was adopted in the mid twentieth century as an official or semi-official language by many newly independent states. English is now represented in very continent, and in island of three major oceans - Atlantic (St. Helena), Indian (Seychelles) and Pacific (in many islands, such as Fiji and Hawaii). It is this spread of representation which makes the application of the label 'global language' a reality.

Most of topics that always discussed in the English lesson are about the differences between AmE and BrE, (John Algeo, 2006) said that the most obvious difference between $\mathrm{BrE}$ and $\mathrm{AmE}$ is in the "tune" of the language, that is, the intonation that accompanies 
sentences. When a Briton or an American talks, he identifies himself primarily by the tunes of his respective varieties, pronunciation and grammar.

English has many contents inside such as grammar, vocabulary, pronunciation, and etc. Grammar is a set of rules of language that arrange the order of it than it will be a perfect sentence, as said by Richard and Schmidt that grammar is a description of the structure of language and how language units such as words and phrases are formed into sentences (Richard and Schmidt in Muh. Saeful Effendi, at al., 2017). The next definition, grammar is a set of rules or principles of the working of a language, its system structure (Brinton in Muh. Saeful Effendi, at al., 2017). Then the definition of vocabulary is little bit complicated because it has many definitions, however little bit complicated (Schmitt in Iman Alizadeh, 2016) argued that vocabulary as the knowledge of words and word meanings. Or someone else may define vocabulary as a list of words arranged in alphabetical order with their definitions. A word, in most linguistic analyses, is described as a set of properties, or features, each word is the combination of its meaning, register, association, collocation grammatical behavior, written form(spelling), spoken form (pronunciation) and frequency. And we can find lots of definitions about the other subjects on many books or articles.

In accordance with the statements above we know that the spread of English was so wide and English also has many differences. the researcher therefore will focus about two differences between $\mathrm{AmE}$ and $\mathrm{BrE}$, and the researcher will focus on two types of differences those are vocabulary and grammar between AmE and BrE. When the people who start to learn English, they will need some vocabularies and they will need some literatures such as grammar to mastery the English. The purpose of this study is to support previous study about several differences between AmE and BrE and why it happened.

\section{METHODS}

In this research the researcher used Qualitative Approach because the researcher wanted to explain the results in words form, therefore the researcher used this approach based on Sugiyono's opinion $(2016,11)$ that qualitative research aims to construct and to interpret then will explain the issues that studied. 


\section{JLIC}

While Library Research is the type of research that researcher used because the sources of this research are to study about several book, articles and others to get the conclusion what this research means, then the researcher explained this research descriptively with deductive and inductive analyses that Library Research use frequently and search the cause of problem of this research. This is in accordance with (Moh. Kasiram, 2010) that Library Research must be comprehensive; it means that could observe all of the problem research, so it could support the discussion and solve the problem clearly.

\section{RESULTS AND DISCUSSION Grammar Differences}

1. Past and Past Participle Forms of Verb

Differences in verb forms are acknowledge as perhaps the most significant dissimilarity between $\mathrm{BrE}$ and $\mathrm{AmE}$. A number of $\mathrm{BrE}$ verbs have a $t$-inflection while AmE verbs tend to conform to the standardized -ed structure. These differences constitute a subtle distinction in pronunciation which on ten goes unnoticed (in pronunciation), but indicate in which English a text is written. It is worth mentioning that many AmE conjugations are considered standard in $\mathrm{BrE}$, thus both versions are accepted as correct (Modiano in Md. Faruquzzaman, 2017). Though the irregular past form such as dreamt, spelt etc are possible in Amereican English, they are less common than the forms ending in -ed. Here is the diagram for verbs showing different simple past and past participle forms in BrE and AmE. 
Table 1. BrE and AmE Past and Past Participle Forms of Verb (Modiano in Md. Faruquzzaman, 2017)

\begin{tabular}{llll}
\hline & Infinitife & Simple Past & Past Participle \\
\hline$B r E$ & \multirow{2}{*}{ Burn } & Burnt/burned & Burnt/burned \\
$A m E$ & & Burned/burnt & Burned/burnt \\
\hline$B r E$ & \multirow{2}{*}{ Bust } & Bust & Bust \\
$A m E$ & & Busted & Busted \\
\hline
\end{tabular}

\begin{tabular}{llll} 
BrE & Dream & Dreamt/dreamed & Dreamt/dreamed \\
AmE & & Dreamed/dreamt & Dreamed/dreamt \\
\hline$B r E$ & \multirow{2}{*}{ Get } & Got & Got \\
AmE & & Got & Gotten \\
\hline Bre & \multirow{2}{*}{ Learn } & Learnt/learned & Learnt/learned \\
$A m E$ & & Learned/learnt & Learned/learnt \\
\hline$B r E$ & \multirow{2}{*}{ Smell } & Smelt/smelled & Smelt/smelled \\
$A m E$ & & Smelled/smelt & Smelled/smelt \\
\hline$B r E$ & \multirow{3}{*}{ Wake } & Woke & Woken \\
$A m E$ & & Woke/woked & Woken \\
\hline
\end{tabular}

2. Past Simple Vs Present Perfect

(Don R. McCreary, 2003) had written an article on Online monthly MED Magazine, American speakers tend to use the present perfect- less than British speakers, often using the simple past instead, especially in sentences with words like just, yet, already. For example:

British (and American) English: Have you eaten yet?

American English : did you eat yet?

British (and American) English: Has Sam just left? Sam has left already? 


\section{JLIC}

American English $\quad$ : Did Sam just leave? Sam left already?

(Don R. McCreary, 2003)

In the other hand (Bin Zhang, 2008) wrote on his article that in British English, the adverbs "yet" and "already" cannot be used in past tense and can only be used in past perfect tense. However, in AmE, they can be used both in past tense and pas perfect tense. For example:

I haven't bought one yet. (BrE and AmE)

I didn't buy one yet. (AmE)

Have you read it already? ( $\mathrm{BrE}$ and $\mathrm{AmE})$

Did you read it already? (AmE)

(Bin Zhang, 2008)

Dylan Lyons also wrote his article on Babbel Magazine that Americans tend to use the past simple tense when describing something that has currently occurred, while people in the U.K. are more likely to use the present perfect tense.

Table 2. AmE and BrE Past Simple Vs Present Perfect (Dylan Lyons, 2020)

\begin{tabular}{ll}
\hline AMERICAN ENGLISH & BRITISH ENGLISH \\
\hline I ate too much & I have eaten too much \\
\hline I went to the store & I have been to the shop \\
\hline Did you get the newspaper? & Have you got the newspaper? \\
\hline
\end{tabular}

3. Prepositions

Differences between AmE and BrE in prepositions are shown in the following to aspects: (1) different use of prepositions in the construction of phrases; (2) when using phrases, one will use a preposition while the other will omit it (Bin Zhang, 2008). Examples:

Your daughter's name stands first in the list. (BrE)

Your daughter's name stands first on the list. (AmE) 
He will come here at a quarter to three. (BrE, AmE)

He will come here at a quarter before /of /till three. (AmE)

(Bin Zhang, 2008)

The same statement is declared by (Dylan Lyons, 2020) that the differences below are only a general rule, American speech has influenced Britain via pop culture, and vice versa. Therefore, some prepositional differences are not as pronounced as they once were.

Table 3. AmE and BrE Prepositions (Dylan Lyons, 2020)

\begin{tabular}{ll}
\hline \multicolumn{1}{c}{ AMERICAN ENGLISH } & \multicolumn{1}{c}{ BRITISH ENGLISH } \\
\hline $\begin{array}{l}\text { I am going to a party on the } \\
\text { weekend. }\end{array}$ & $\begin{array}{l}\text { I am going to a party at the } \\
\text { weekend }\end{array}$ \\
\hline Monday through Friday & Monday to Friday \\
\hline $\begin{array}{l}\text { It's different from/than the } \\
\text { others. }\end{array}$ & $\begin{array}{l}\text { It's different from/to the } \\
\text { others. }\end{array}$ \\
\hline
\end{tabular}

4. Subject-verb Agreement

$\mathrm{BrE}$ and AmE have a lot of dissimilarities in subject-verb concord (Modiano in Md. Faruquzzaman). With a singular collective noun, BrE can prefer using either a singular or plural verb whereas a singular verb is used in AmE (Quirk et al in Md. Faruquzzaman). So, in British English, collective nouns (i.e. nouns referring to particular groups of people or things-government, team, people, class etc.) can be followed by both a singular or plural verb depending on whether the group is thought of as one idea or as many individual. e.g.

My team is winning. Vs. His team are all sitting down.

(Modiano in Md. Faruquzzaman, 2017)

While in AmE, collective nouns are followed by a singular verb, so an American would usually say:

Which team is losing? NOT "Which team are losing" (Modiano in Md. Furuquzzaman, 2017) 


\section{JLIC}

But in British English, both plural and singular forms the verb are possible. e.g. "Which team is/are losing?"

Don R. McCreary (2003) said on his article that in British English, collective nouns, (referring to groups of people) are often followed by a plural verb even the noun is singular. This does not occur in AmE. For example:

$\mathrm{BrE} \quad$ : The football team are rather weak this year.

AmE : The football team is very weak this year.

(Don R. McCreary, 2003)

Other common collective nouns that often take a plural verb in British English are: army, company, jury, audience, crowd, majority, class, enemy, staff, committee, government and union.

5. Articles

There is a remarkable difference in the use of articles in BrE and AmE. For example, BrE has both use of 'a' even with words beginning with vowel sounds in informal use such as $a$ orange. Whereas AmE has a striking use of definite articles with some words such as hospital, university etc. e.g.

BrE- He is in hospital. (BrE- a patient)

AmE- $\mathrm{He}$ is in the hospital. (BrE- other than a patient)

BrE- He is at university.

AmE- He is at the university.

(Tottie in Md. Faruquzzaman, 2017)

Bin Zhang (2008) said that Most phrases of British English have articles, while those of American English do not have. The "the" in the standard expressions in British "all the afternoon", "all the winter", "all the week", "this time of the year", etc. are usually omitted in AmE. For examples: 
The swimming pools are open all summer I will be here all afternoon

He has gone all week

(Bin Zhang, 2008)

British English will use articles in front of "sickness" and "river", while AmE does not. For example, British English expresses in the form of "the measles", "the mumps", "the flu", "the Niagara Falls" and "Black Creek", while AmE says "measles", "mumps", "flu”, "Niagara Falls" and "Black Creek".

However, there are exceptions. In some expressions, BrE does not use articles, while AmE does.

Table 4. AmE and BrE Articles (Bin Zhang, 2008)

\begin{tabular}{ll}
\hline AmE & BrE \\
\hline Go into the hospital & Go into hospital \\
\hline In the hospital & In hospital \\
\hline At university & At the university \\
\hline
\end{tabular}

6. Writing Dates

Dictionary.cambridge.org said on their site that "we write the date in English in different ways. The most common way in British English is to write the day of the month first than the month (starting with a capital letter) and then the year.

20 January 1993, 14 November 2005

We can also write the date in numbers only:

20 January $1993=20 / 1 / 1993$

14 November $2005=14-11-2005$ or 14.11 .05

Sometimes the last two letters of the number as spoken can be used (th, rd, st, nd):

Today is the $7^{\text {th }}$ September

The grand opening in on $1^{\text {st }}$ June. or ... on June $1^{\text {st }}$. 


\section{JLIC}

With the exception of May and June, months can be shortened as follows:

Jan, Feb, Mar, Apr, Jul, Aug, Sept, Oct, Nov, Dec.

Dates in American English, the month of the date come before the day and year. For example, Independence Day in the USA is on July $4^{\text {th }}$ each year. In the year 2000 the date was 4/7/2000 in British English. In American English this is written 7/4/200o."

\section{Vocabulary Differences}

Lexicon or vocabulary is a central linguistic area where are noticeable differences between BrE and AmE. Milward in Ashraf Abdel (2018) suggests that the three main semantic areas where there are differences between $\mathrm{BrE}$ and AmE English are food, clothing and transportation. The vagaries of fashion have caused divergence in the of clothing. The many differences in the terminology of transportation result from the fact that the railroad (British "railway") and motorcar industries, developed after the separation of the United States and Great Britain.

Therefore, the following tables show some examples regarding the differences in vocabulary between BrE and AmE.

Table 5. AmE and BrE Vocabulary Differences (Milward in Ashraf Abdel, 2018)

\begin{tabular}{ll}
\hline Food & \\
\hline British English & American English \\
\hline Biscuits & Cookies or crackers \\
Chips & French fries \\
Crisps & Potato chips \\
Jelly & Jello \\
Mince & Humburger \\
\hline Clothing & \\
\hline British English & American English \\
\hline Pants & Underpants \\
Overall & Smock \\
Knickers & Women's underpants \\
Trainers & Running shoes \\
Waistcoat & Vest \\
\hline
\end{tabular}




\begin{tabular}{ll}
\hline Transportation & \\
\hline British English & American English \\
\hline High street & Main street \\
Caravan & Trailer \\
Motorway & Turnpike \\
Roundabout & Traffic circle \\
\hline
\end{tabular}

British Council and Bin Zhang (2008) add some vocabularies on their site's article that have some differences between AmE and BrE, here are the samples:

Table 6. AmE and BrE Vocabulary Differences (British

Council, 2020)

\begin{tabular}{ll}
\hline General & \\
\hline British English & American English \\
\hline Flat & Apartment \\
University & College \\
Theatre & Theater \\
Holiday & Vacation \\
The cinema & The movies \\
Soft drink / fizzy drink & Soda / pop / coke / soft drink \\
Jumper & Sweater \\
Postbox & Mailbox \\
Football & Soccer \\
Trousers & Pants \\
Trunk call & Long Distance Call \\
Parcel & Package \\
Junction, crossroads & Intersection \\
Sweets & Candy \\
\hline
\end{tabular}

The first complete America's Dictionary has been accomplished in 1828 by a lawyer and lexicographer named Noah Webster. He argued briefly that English in America is different with English in Britain (Nurhendi, 2016).

The following example are several differences vocabulary between Ame and BrE: 


\section{JLIC}

Table 7. AmE and BrE Vocabulary Differences (Nurhendi, 2016)

\begin{tabular}{ll}
\hline British English & American English \\
\hline Ground floor & First floor \\
Dustman & Garbage collector \\
Lorry & Truck \\
Petrol & Gasoline \\
Chemist & Drugstore \\
Wash up & Do the dishes \\
Jug & Pitcher \\
Rubber & Eraser \\
Bowler / hat & Derby / hat \\
Aero plane & Airplane \\
Flyover & Overpass \\
\hline
\end{tabular}

\section{CONCLUSION}

Although there are many differences between AmE and $\mathrm{BrE}$ in many ways such as grammatical and vocabulary. they are mostly similar each other and they can understand each other in their daily conversation, but the difficulty might appear if the new learners begin learning English. It is common to whoever will start learning English, because the differences are very visible. In addition, the differences between AmE and BrE especially in grammar and vocabulary may become a problem to beginner if they want to take English for academic purposes, because $\mathrm{BrE}$ and $\mathrm{AmE}$ have a special standardized.

\section{REFERENCES}

Akan, Md. Faruquzzaman. (2017). "A Profile of the Grammatical Variation in British and American English". Journal of English Language Teaching and Linguistics).2 (3): 201-214.

Algeo, John. (2006). "British or American? A Handbook of Word and Grammar Patterns". Cambridge University Press. United States.

Alizadeh, Iman. (2016). "Vocabulary Teaching Techniques: A Reviw of Common Practices". International Journal of Research of English Education.1 (1). 22-30. 
Antonio, Abigal F. (2019). "American or British? A Corpus-Based Analysis of Asian Englishes' Orthographical Norms". Asian EFL Journal".26 (6): 1-26.

Baugh, Albert C. \& Thomas Cable. (2002). "The History of The English Language". Routledge. London

Brinton, J. Laurel \& Donna M. Brinton. (2010). "The Linguistic Structure of Modern English”. John Benjamins Publishing Company. Philadelphia

Crystal, David. (2003). "English as a Global Language". Cambridge University Press. United States.

Dictionary, Cambridge. "Writing The Date". Accessed at $25^{\text {th }}$ July 2020.https://dictionary.cambridge.org/grammar/britishgrammar/dates

Effendi, Muh. Saeful, et al. (2017). "A Study on Grammar Teaching at an English Education Department in an EFL Context". International Journal on Studies in English Language and Literature. 5 (1). 42-46.

Fares, Ashraf Abdel Fattah Musleh Abu, (2019). "British English And American English: History and Differences". International Journal of Linguistics, Literature and Translation.2 (1): 176187.

Foundation, British Council. "Differences Between American and British English. Accessed at $25^{\text {th }}$ July 2020. https://www.britishcouncilfoundation.id/en/english/articles british-and-american-english

Kasiram, Moh. (2010). "METODOLOGI PENELITIAN Refleksi Pengembangan Pemahaman dan Penguasaan Metodologi Penelitian”. UIN-Maliki Press. Malang. 


\section{JLIC}

Lyons, Dylan. (2020). "What Are The Differences Between American And British English?". Babbel MAGAZINE. from https://www.babbel.com/en/magazine/what-are-thedifferences-between-american-and-british-english

McCreary, Don R. (2003). "British And American English". MED MAGAZINE: The Monthly Webzine of The Macmillan English Dictionaries. From http://www.macmillandictionaries.com/MEDMagazine/October2003/12-language-awareness-britishamerican-uk.htm.

Nurhendi. (2016). "American English vs British English". Harfeey. Yogyakarta.

Sugiyono. (2016). "Metode Penelitian Kuantitatif, Kualitatif dan R\&D. Alfabeta. Bandung.

Zhang. Bin. (2008). "On Grammatical Differences Between Daily British and American English". Asian Social Sciene.4 (6). 6973 . 